\title{
ESTIMATE OF RADON EXPOSURE IN GEOTHERMAL SPAS IN POLAND
}

\section{KATARZYNA WALCZAK, JERZY OLSZEWSKI, and MAREK ZMYŚLONY}

Nofer Institute of Occupational Medicine, Łódź, Poland

Department of Radiological Protection

\begin{abstract}
Objectives: Geothermal waters may contain soluble, radioactive radon gas. Spa facilities that use geothermal water may be a source of an increased radiation dose to people who stay there. It has been necessary to assess the exposure to radon among people: workers and visitors of spa centers that use geothermal waters. Material and Methods: In 2013, workers of the Nofer Institute of Occupational Medicine measured concentrations of radon over the geothermal water surfaces in 9 selected Polish spa centers which use geothermal water for recreational and medicinal purposes. The measurements were performed by active dosimetry using Lucas scintillation cells. Results: According to our research, the doses received by the personnel in Polish geothermal spas are $<0.6 \mathrm{mSv} / \mathrm{year}$. In 1 of the investigated spas, the estimated annual dose to the staff may exceed $3 \mathrm{mSv} / \mathrm{year}$. Conclusions: In Polish geothermal spas, neither the workers nor the visitors are at risk of receiving doses that exceed the safe limits.
\end{abstract}

Key words:

Poland, Occupational exposure, Worker, Radon, Ionizing radiation, Spa visitor

\section{INTRODUCTION}

Radon ${ }^{222} \mathrm{Rn}$ is formed as a result of natural transformation of radioactive uranium isotope ${ }^{238} \mathrm{U}$ which is found in the Earth's crust in quantities of 2.4 parts per million on average.

The presence of radon is quite common. Its elevated levels are found in the majority of enclosed or poorly ventilated areas in contact with soil or groundwater. This happens because firstly - radon is gas and it easily migrates in the soil. It may seep into ground facilities through slits in the crust and micro-cracks in building units. Secondly radon is highly soluble in water. Water flowing in underground riverbeds may contact uranium deposits. These are the places where radon is produced in large amounts. Radon is flushed out by water, and since it has a half-time of 3.8 day, it may be transported over quite long distances. In some areas this phenomena may cause high concentrations of radon to accumulate unexpectedly without the direct presence of uranium compounds.

It seems that the risk of elevated concentrations of radon in the air may be greater in geothermal spas because the source of geothermal waters extend far into the ground, which increases the likelihood of water contacting the uranium deposits.

It should be remembered that, according to Henry's law (which describes the behavior of liquid binary mixtures) with increasing temperature, the solubility of radon in water decreases, and its concentration in the air increases [1]. Accordingly, in poorly ventilated, enclosed spa facilities that use geothermal water, radon concentrations in the air

This work has been carried out under Nofer Institute of Occupational Medicine statutory Grant No. IMP 16,7/2013. Grant manager: J. Olszewski, Ph.D. Received: July 31, 2014. Accepted: May 11, 2015.

Corresponding author: K. Walczak, Nofer Institute of Occupational Medicine, Department of Radiological Protection, św. Teresy 8, 91-348 Łódź, Poland (e-mail: kwalczak@imp.lodz.pl). 
may reach higher levels than in other confined spaces, such as residential buildings where radon comes mainly from the ground.

Geothermal water is defined as underground water, the certain temperature of which is not less than the one set out for the given country at the outlet of the source. Thus, according to the Geological and Mining Law Act of 9 June 2011 [2], in Poland temperatures of geothermal water are to be not $<20^{\circ} \mathrm{C}$ whereas, for example in the USA, they are $>21^{\circ} \mathrm{C}$.

Even though the source is geothermal, the outflowing water may become cold. Water may be even as cool as $15^{\circ} \mathrm{C}$. In other cases, the water is too hot to be used directly from the source. In order to regulate the temperature of spa water from a geothermal source, it is often mixed with tap water. Diluting tap water may cause an amount of radon per unit of water volume to fall. It does mean that if someone were to use geothermal water directly from the source, the water may contain higher radon concentration than it was estimated during measurement in bathtub or swimming pool water.

Radon and some of its decay products (polonium ${ }^{218} \mathrm{Po}$, lead ${ }^{214} \mathrm{~Pb}$ and polonium ${ }^{214} \mathrm{Po}$ ) emit, among others, $\alpha$ particles. These particles constitute a threat to the human body because they ionize other particles (give them high energy), and may induce changes in the construction of the tissues, especially when they get into the respiratory tract. The irradiation of bronchial epithelium due to radon progenies may lead to DNA breaks and, as a result, give rise to mutations and carcinogenic processes.

Radon is odorless and colorless, so it is not detectable without the use of specialized equipment.

The aim of this study has been to preliminary estimate radon concentrations and doses that are possible to derive in the air of the spas that use geothermal water for medicinal and recreation purposes. Based on the concentrations and the annual time spent in a spa center it has been possible to assess the exposure to radon among workers and visitors.
The need to carry out the research in this area in Poland was motivated by our previous analysis of reports on similar measurements all around the world [3]. In this study radon concentrations were analyzed in the air of 17 geothermal centers: in Greece ( 3 centers), Iran (5), China (4) and India (5). We have found that radon levels in spas are from a few to several times higher than those in confined spaces where geothermal waters are not used (e.g., residential buildings). In $82 \%$ of the analyzed spas, workers may receive doses above $1 \mathrm{mSv} / \mathrm{year}$. Except for 1 case, doses did not exceed $6 \mathrm{mSv} / \mathrm{year}$. According to the relevant Polish regulations, workers receiving doses higher than $1 \mathrm{mSv} / \mathrm{year}$ are included in the category $\mathrm{B}$ of radiation exposure and require regular dosimetric monitoring. Doses received by spa visitors are much lower because the time of their exposure to radon released from geothermal water is rather short. Another analysis of radon concentration in spa facilities in the world shows that the radiological protection of people working with geothermal waters plays an important role [4,5]. It seems reasonable to include spa workers staying close to geothermal waters into a dosimetric monitoring programme.

\section{MATERIAL AND METHODS}

In 2013 we measured concentrations of radon over the geothermal water surfaces in 9 selected Polish spa centers which use geothermal water for recreational and medicinal purposes (few spa didn't allow us to perform measuring). Eight of the surveyed centers use geothermal water in swimming pools and a jacuzzi. In 1 of the spas, designed for therapeutic use of geothermal waters, the resort has a relaxing bathtub filled in with geothermal water, which also features a device producing bubbles.

The measurements were performed by means of active dosimetry. There are a lot of ways to measure radon concentration [6] but we chose the Lucas scintillation cells because this is one of the best methods to measure the radon levels in the air in a short period of time. 
In order to estimate the maximum exposure to the human respiratory tract, most of the air samples were collected just above the surface of the water in the tank with geothermal water. It is because this is the breathing zone for the spa visitors. Further radon is 8 times heavier than the air, and just above the surface of water, the area where radon reaches the highest levels is found. Other air samples were taken in the employees' zone. For the purpose of collecting the samples, 0.251 of the radioactive air was pumped into the Lucas scintillation cells. Readings from the scintillation cells were taken after the radioactivity had reached an equilibrium, i.e. about $3 \mathrm{~h}$ after collecting the sample. In order to read the radon concentration from Lucas cells, the mining radiometer type RGR-13 provided with a head type FG-10 was used.

The conversion coefficient proposed by the International Atomic Energy Agency (IAEA) in the report No. 33 [7] was used to estimate the doses received by people in the spas. In this report it was assumed that $1 \mathrm{~h}$ exposure for occupational exposure to $1 \mathrm{~Bq} / \mathrm{m}^{3}$ of radon concentration and the equilibrium factor $\mathrm{F}=0.4$ correspond to an effective dose of $3.2 \mathrm{nSv}$ [7]. We assumed that the equilibrium factor in geothermal spas was the equivalent of $\mathrm{F}=0.4$ because, according to the International Commission on Radiological Protection's (ICRP) report [8], if the equilibrium factor is unknown, for most purposes it is adequate to use the equilibrium factor of 0.4 for work and indoor occupancy.

Samples were collected mainly in the morning, before the bathers entered the pool halls, or in the afternoon, when bathers left the halls. According to the size and number of the geothermal water tanks in every spa, 5-7 air samples were collected. We estimate that in all the spas under consideration, there may be about a few hundred employees, and they spend about $2000 \mathrm{~h}$ per year in the geothermal area. Our interests focused just on radon concentration existence, we were not considering radon variation within a day, or according to the season. Measurements were performed once in every spa center during 1 year in summer and autumn, and based on this we estimated an annual effective dose for workers and visitors. As it was just a preliminary study about the presence of radon concentration in spas, more detailed measurements (including measurements at different parts of the year) we want to perform in the future.

\section{RESULTS}

Radon concentration from all of collected samples, except for 1, was below the range of the lower detection limit of Lucas scintillation cells, that is $100 \mathrm{~Bq} / \mathrm{m}^{3}$. It does mean that the maximum dose that may be received by the staff in Polish geothermal spas is not higher than $0.6 \mathrm{mSv} / \mathrm{year}$. Only in 1 of the investigated spas, radon concentration was within the range of $130-530 \mathrm{~Bq} / \mathrm{m}^{3}$, so the estimated annual dose for the staff may be $0.8-3.4 \mathrm{mSv}$.

\section{DISCUSSION}

According to the Polish legislation [9] (Atomic Law, which is an implementation of the European Directive [10]), the owner of any establishment where the personnel is likely to receive doses ranging 1-6 $\mathrm{mSv} / \mathrm{year}$, is required to qualify the area as the category $B$ radiation exposure and is obliged to include the people staying there into a dosimetric monitoring programme. Those limits of doses do not concern spas specifically but the occupational exposure to ionizing radiation. Because there is no implementing rule regarding spas in Poland, we compared doses received in spas with the limits we know. Doses that we have estimated, except for 1 single case quoted above, do not exceed the recommended safe limits specified in the Atomic Law.

The radon concentration values measured by us in the air of Polish spa resorts are slightly lower than the natural concentration background from the indoor radon, which are calculated to be within the range of 114-249 Bq/ $\mathrm{m}^{3}$ [11]. According to the Authors' previous study [3], globally 
in $82 \%$ of the surveyed geothermal spa establishments there is a risk that the staff receive doses above $1 \mathrm{mSv} / \mathrm{year}$, and in $6 \%$ of them - above $6 \mathrm{mSv} / \mathrm{year}$. In our opinion, visitors of the spa, who spend at the spa considerably less time than the staff, may obtain correspondingly smaller doses (doses to patients may be even 1000 times lower). Another investigation in Polish geothermal spas was conducted by Nowak [12]. He estimated the risk of receiving doses to the staff's lungs, by calculating data collected from samples of geothermal water, not from the air above the geothermal surface. Nowak only estimated the amount of water drops in the air above the surface of the geothermal water (which enlarges the error of the calculation), and then, based on his earlier radon measurement in the water samples, calculated how many nuclides are contained in the air unit volume. Next he calculated the dose to the lung. Unlike Nowak, we collected the air samples with water drops in them directly from above the water surfaces, and then we calculated doses to the lung (thus, we have obtained real, not theoretical, data of contents of the nuclides in the air unit volume). Doses calculated by Nowak are congruent to ours. Nowak estimated that in almost all the spa centers under consideration, the staff is at the risk of receiving doses ranging about $0.2-0.6 \mathrm{mSv} /$ year. According to him, in 1 spa resort the dose may be significantly higher than in the other spa resorts. We have calculated that in the same spa resort the staff may receive doses ranging 0.8$3.4 \mathrm{mSv} / \mathrm{year}$, while Nowak's calculations show that the dose may be as high as $10 \mathrm{mSv} / \mathrm{year}$. The difference between the results of these 2 studies may be explained, for example, in terms of differences in: the way of estimating the dose (we measured radon concentration directly from the air, and he calculated the radon concentration in the air, based on the radon concentration in the water), places of sampling, season, or height above the ground level [12].

We think, that those high doses are probably related to the geological structure of the regions where geothermal water comes out. Definitely higher concentrations of radon may be expected in the areas where uranium mineralization and geothermal water occur simultaneously. Probably this is the reason why in most geothermal centers in Poland there are no doses exceeding the safe level, while doses in similar centers worldwide are sometimes exceeded. The same conclusion was reached by Nowak, when he indicated that high doses in spa resorts, where the staff may receive doses above $10 \mathrm{mSv} / \mathrm{year}$, may be the result of contact of the geothermal water with rock formations that contain numerous uranium-rich granitoid intrusions [12].

We analyzed the presence of uranium deposits in Poland. We compiled a map of known uranium deposits and uranium mineralization occurring in the Polish geological units based on the Solecki et al.'s and Kubski et al.'s works $[13,14]$. The map on the Figure 1 shows the probable locations of uranium mineralization and zones of geothermal waters in the area of Poland. The information about the zone of geothermal waters is based on Kubski's work [14]. There is uncertainty about the shape of the uranium mineralization zones.

On the map there are also all of the investigated by us spas and main cities of Poland, that are marked to make the location easier. The spa with the highest value of radon concentration is marked in the Figure 1 in order to make the link with the areas with uranium mineralization. As it may be seen from the Figure 1, not every spa, that is located near uranium mineralization, has elevated radon concentration. It may be explained by differences in density and permeability of earth crust.

The Figure 1 shows that Poland has great potential when it comes to geothermal spas. There are a lot of places where new geothermal spas might be launched. It is obvious that, if new spa facilities are launched, in places where uranium mineralization and zone of geothermal water coincide, the risk of increased radon concentration at those locations may be high. We have measured radon concentration in all spas in Poland available for us, paying particular attention to those which are located where uranium mineralization and zone of 


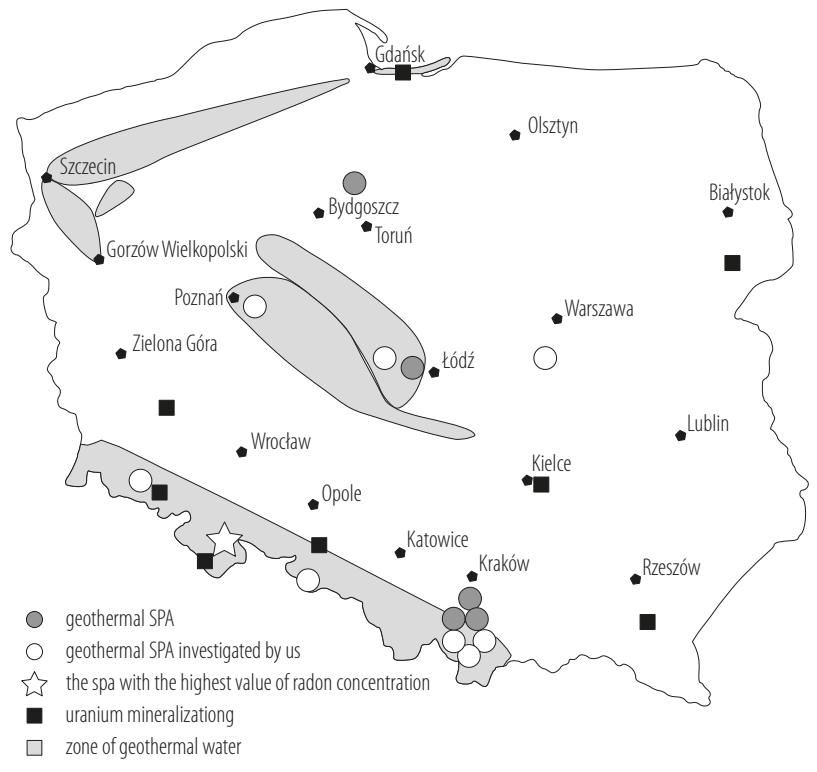

Based on the data after Solecki et al. [13] and Kubski et al. [14].

Fig. 1. Best known areas of thermal water and of uranium mineralization in Poland

geothermal water coincide. We have found that in such places the risk of high radon concentration may be high. In the North of Poland, near the Vistula Spit, there are still possibilities for new spa facilities to be launched because of the large zone of geothermal water located there (there is uranium mineralization also located). It will be necessary to pay particular attention to radiation protection in such spa centers.

The measurements performed by us have shown that doses we have calculated for most of Polish spas are below the occupational exposure thresholds, so the workers do not necessarily have to be included into a dosimetric monitoring programme. However, before new spa facilities are launched in uranium mineralization areas (the Vistula Spit, the Holy Cross Mountains, the Sudetes) radiation doses at each new location should be reliably estimated.

\section{CONCLUSIONS}

1. At this moment, in Polish geothermal spas, neither the workers nor the patients are at risk of receiving excessive doses of radon radiation.
2. The new spas, particularly those launched in areas with uranium mineralization, should first be tested for radon in the air over the water pools.

\section{REFERENCES}

1. Hołyst R, Poniewierski A, Ciach A. [Thermodynamics for chemists, physicists and engineers: Perfect solution diluted. Henry's law]. Warszawa: Instytut Chemii Fizycznej, PAN i Szkoła Nauk Ścisłych; 2003. p. 172-4. Polish.

2. [The Act of 9 June 2011 on geological and mining law. $J$ Laws 2011, No. 163, item 981, article 5.2]. Polish.

3. Walczak K, Zmyślony M. [Estimation of effective doses derived from radon in selected SPA centers that use geothermal waters based on the information of radon concentrations]. Med Pr. 2013;64(2):193-8, http://dx.doi.org/10.13075/ mp.5893/2013/0015. Polish.

4. Sola P, Srisuksawad K, Loaharojanaphand S, O-Manee A, Permnamtip V, Issarapan P, et al. Radon concentration in air, hot spring water, and bottled mineral water in one hot spring area in Thailand. J Radioanal Nucl Chem. 2013;297:183-7.

5. Pugliese M, Quarto M, Roca V. Radon concentrations in air and water in the thermal spas of Ischia Island. Indoor Built Environ. 2013 Apr;23(6):1-5.

6. George AC. State-of-the-art instruments for measuring radon/thoron and their progeny in dwellings - A review. Health Phys. 1996 Apr;70(4):451-63, http://dx.doi.org/ 10.1097/00004032-199604000-00001.

7. Radiation protection against radon in workplaces other than mines. Safety reports series No. 33. Vienna: International Atomic Energy Agency; 2003. p. 27-8.

8. International Commission on Radiological Protection. Protection against radon-222 at home and at work. A report of a task group of the International Commision on Radiological Protection. Ann ICRP. 1993 Dec;23(2):1-45.

9. [The Act of 29 November 2000 on atomic law. J Laws 2001, No. 3, item 18]. Polish.

10. Council directive 96/29/Euratom of 13 May 1996 laying down basic safety standards for the protection of the health of workers 
and the general public against the dangers arising from ionizing radiation. Off J Eur Comm 159, 29.06.1996 (Jun 29, 1996).

11. Przylibski TA, Żebrowski A, Karpińska M, Kapała J, Kozak K, Mazur J, et al. Mean annual ${ }^{222} \mathrm{Rn}$ concentration in homes located in different geological regions of Poland - First approach to whole country area. J Environ Radioact. 2011; 102:735-41, http://dx.doi.org/10.1016/j.jenvrad.2011.03.018.

12. Nowak J. [Natural radioactivity of the thermal waters of the Polish Carpathians] [dissertation]. Kraków: Akademia
Górniczo- Hutnicza im. S. Staszica w Krakowie, Wydział Fizyki i Informatyki Stosowanej; 2013. Polish.

13. Solecki A, Śliwiński W, Wojciechowska I, Tchorz-Trzeciakiewicz D, Stryczyński P, Sadowska M, et al. [Possibilities of occurrences of uranium mineralization in Poland as shown by results of geological prospecting]. Przegl Geol. 2011;59(2):98-110. Polish.

14. Kubski P. [Geothermal heating plant in Stargard Szczeciński and its collapse]. Instal. 2008;2:20-4. Polish.

This work is available in Open Access model and licensed under a Creative Commons Attribution-NonCommercial 3.0 Poland License - http://creativecommons.org/ licenses/by-nc/3.0/pl/deed.en. 